\title{
Hypothalamic Hamartoma
}

National Cancer Institute

\section{Source}

National Cancer Institute. Hypothalamic Hamartoma. NCI Thesaurus. Code C4385.

A benign, disorganized mass of various mature cells, located heterotopically in the

hypothalamus; it is often associated with endocrine and neurological conditions, such as precocious puberty and gelastic seizures. 